\title{
SPEI and Hurst Analysis of Precipitation in the Amazonian Area of Brazil
}

\author{
Humberto Millán Vega ${ }^{1}$ (D), Jakeline Rabelo Lima ${ }^{1}$, Samuel Nogueira Cerniak ${ }^{1}$ \\ ${ }^{1}$ Centro de Estudos Superiores de Tefé, Universidade do estado do Amazonas, \\ Manaus, AM, Brasil.
}

Received: 25 April 2018 - Accepted: 22 October 2018

\begin{abstract}
Amazon rainforest controls, to some extent, the global hydrological cycle. The objectives of the present work were (i) to investigate hydrologicalpatterns in a larger regionof the Brazilian rainforestthrough 9-month SPEI series and (ii) to search for long or short-term correlation within the number of days with precipitation by monthand accumulated monthly rainfall. Data sets were collected from 15 meteorological stations spanning a large area of the Amazonian rainforest in Brazil. We computed SPEI values from monthly precipitation and monthly meantemperature time series and determined Hurst exponents from detrendedtime series of days with precipitationand accumulated monthly rainfall. In the first case $S P E I$ was determined on a 9-month timescale while Hurst exponents were calculated from rescaled range analysis. Percentage of $S P E I$ values in the near normal class $(-1 \leq S P E I \leq 1)$ ranged from $59.8 \%$ (Peixe, TO) to 69.7\% (Tarauaca, AC). The Hurst exponent varied from 0.382 (Diamantino, MT) to 0.636 (Tefé, AM) and correlated positively with the monthly meanrainfall. This indicates a persistenttrend of wet patterns in the futurein some areas. Hurst analysis of days with precipitation and monthly rainfallcould be an additional tool for interpreting rainfall data.
\end{abstract}

Keywords: precipitation, spei, Hurst analysis, Amazonian rainforest.

\section{SPEI e Análise de Hurst da Precipitação na Área Amazônica do Brasil}

\section{Resumo}

A floresta amazônica controla, em certa medida, o ciclo hidrológico global. Os objetivos do presente trabalho foram (i) investigar padrões hidrológicos em uma área maior da floresta tropical brasileira por meio do SPEI baseado em 9-meses e (ii) buscar correlação de longo ou curto prazo dentro do número de dias com precipitaçãoe chuva mensal. Os conjuntos de dados foram coletados de 15 estações meteorológicas que abrangem uma grande área da floresta amazônica. Além disso, calculamos os valores de SPEI a partir de séries temporais mensais de precipitação e de temperatura media e determinamos os expoentes de Hurst a partir de séries temporais padronizadas de dias com precipitaçãoe séries mensais de precipitação. No primeiro caso, o $S P E I$ foi determinado em uma escala temporal de 9 meses, enquanto os expoentes de Hurst foram calculados a partir da análise de escala re-escalonada. O percentual de valores de SPEI na classe normal variou de 59,8\% (Peixe, TO) a 69,7\% (Tarauaca, AC). O expoente de Hurst variou de 0,382 (Diamantino, MT) a 0,636 (Tefé, AM) e correlacionou-se positivamente com os dados de precipitação media. Isso indica uma tendência persistente de padrões úmidos no futuroem algumas áreas. A análise de Hurst de dias com precipitação e chuva mensalpode ser uma ferramenta adicional para interpretar dados de precipitação.

Palavras-chave: precipitação, spei, análise de Hurst, floresta Amazônica.

\section{Introduction}

The Amazon rainforest is the largest ecosystem around the world. It controls, to some extent, the global hydrological cycle (Yoon and Zeng, 2010). In particular, Brazil holds the major part of that ecological reserve. The
Amazon basinhas attracted a lot of investigations in terms of water balance, global carbon cycle or impact of climate change. It is considered one of the regions with strongest convective activity around the world (Andreoli et al. 2012). According to Marengo et al. (2004) precipitations in the Amazon have shown an unclear trend as

Autor de correspondência: Humberto Millán Vega, amaliafigueredo@infomed.sld.cu. 
multidecadal variations have presented opposite tendencies in the northern and southern areas of the basin. In particular, the time period 1950-1976 was wet in northern Amazonia and drier since 1976 (IPCC, 2001). In 2005, western Amazonia recorded its worst drought in 40 years (Zeng et al., 2008). Rainfall variability in Amazonia is correlated with the sea surface temperature (SST) patterns in the Atlantic and Pacific oceans during December, January and February (Martins et al., 2015). On the other hand, past investigations have shown a decadal intensification of rainfall over the whole Amazon basin (Chen et al., 2002).

In general, drought is very hard to define. Mishra and Singh (2010) have presented a review of drought concepts and its impact around the world during recent decades. Aragão et al. (2012) investigated the relationship between droughts and deforestation while Bonini et al. (2014) found significant negative correlations between deforestation and local precipitation in Mato Grosso, southern Brazil. Several statistical methods have been used for monitoring the severity of rainfall shortage. Palmer (1965) proposed the Palmer Drought Severity Index $(P D S I)$ for characterization of meteorological drought. McKee et al. (1993) proposed the standardized precipitation index $(S P I)$ to evaluate drought conditions for various timescales in different scenarios. Drought is usually grouped into meteorological drought (1- to 3- month timescale) to hydrological drought (6- month up to 24- month timescale) in terms of several indexes (Wildhite and Glantz, 1985). However, the main problem is that SPI is based on precipitation data only. This implies that SPI does not recognize the influence of temperature on drought conditions. More recently Vicente-Serrano et al. (2010) proposed the standardized precipitation evapotranspiration index (SPEI) which is based on precipitation and temperature (e.g. evapotranspiration) records. Tsakiris and Vangelis (2005) have stressed on the motivation for using potential evapotranspiration (PET) in drought severity evaluation. Those authors considered that $P E T$ can be considered as a key variable representing the intensity of the atmosphere to extract water from a selected system. Even thoughSPI and SPEI are valuable tools within the context of hydrological sciences, those indexes do not permit to detect hidden trends or to detect the probability of future extreme events. In this context, the rescaled range analysis $(R / S)$ developed by Hurst (1951) to predict Nile River flooding could be a valuable tool for a better analysis and interpretation of SPEI time series. This nonlinearmethod has been used with rainfall data corresponding to several climatic environments (e.g. Zhou et al., 2005). While traditional drought indicators (e.g. SPI or $S P E I$ ) use one month or one week as the minimal timescale, $R / S$ can analyze smaller timescales (e.g. minutes, hours or days) in terms of up- or down- scaling. Thus, our main hypothesis is that Hurst exponents computed from $R /$
$S$ analyses could be statistically correlated to $S P E I$ values. The objectives of the present work were (i) to investigate hydrologicalpatterns in a larger region of the Brazilian rainforest through 9-month SPEI series and (ii) to search for long- or short-term correlation within the number of days with precipitation by monthand accumulated monthly rainfall.

\section{Material and Methods}

\subsection{Study area and data characteristics}

The study covers an important part of the Amazonian area of Brazil (e.g. from $-48.35^{\circ}$ to $-70.76^{\circ}$ West Longitude and $-16.45^{\circ}$ to $2.82^{\circ}$ South Latitude). The spatial distribution of the meteorological stations is presented in Fig. 1. We considered a total of fifteen sites across seven Amazon states from Brazil. Table 1 shows basic information (e.g. geographical coordinates and height above sea level)about each meteorological station. We collected accumulated monthly rainfall and monthly mean temperature from each meteorological station. In order to investigate recent hydrometeorological patterns, we used uniform rainfall datasets ranging from 2001 to 2015. In addition, the number of days with precipitation by month for the same time period was also collected from each meteorological station.

\subsection{Standardized Precipitation Evapotranspiration Index (SPEI)}

Monthly rainfall and monthly mean temperature records were used for computing the standardized precipitation evapotranspiration index (SPEI) on a 9-month timescale. In particular, that timescale could be convenient for monitoring inter-seasonal hydrological patterns (WMO, 2012). The mathematical rationale of SPEI is well

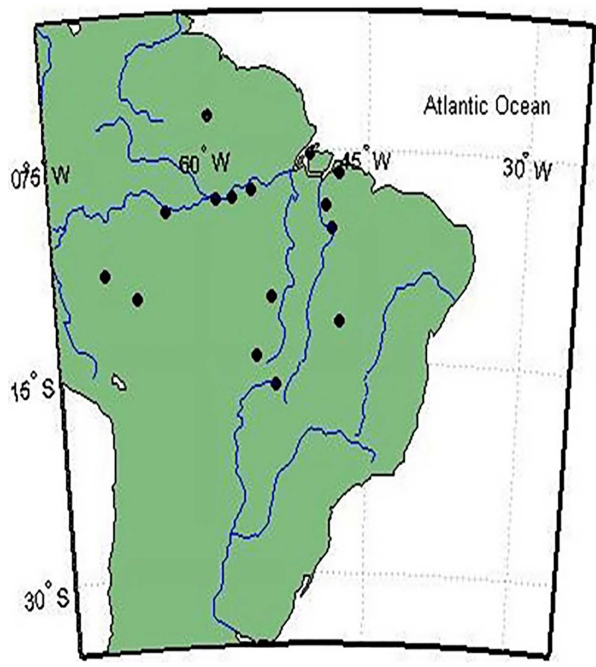

Figure 1 - Geographical location of meteorological stations. 
Table 1. - General information of meteorological stations

\begin{tabular}{|c|c|c|c|c|c|}
\hline $\begin{array}{l}\text { Station } \\
\text { ID }\end{array}$ & Location & State & $\begin{array}{l}\text { Longitude } \\
\quad\left({ }^{\circ}\right)\end{array}$ & $\begin{array}{l}\text { Latitude } \\
\left(\left(^{\circ}\right)\right.\end{array}$ & $\begin{array}{l}\text { h.a.s.1 } \\
(\mathrm{m})^{*}\end{array}$ \\
\hline 82191 & Belem & Pará & -48.43 & -1.43 & 10.0 \\
\hline 82024 & Boa Vista & Roraima & -60.66 & 2.82 & 83.0 \\
\hline 83309 & Diamantino & $\begin{array}{c}\text { Mato } \\
\text { Grosso }\end{array}$ & -56.45 & -14.4 & 286.3 \\
\hline 82336 & Itacoatiara & Amazonas & -58.43 & -3.13 & 40.0 \\
\hline 82098 & Macapá & Amapá & -51.11 & -0.05 & 14.46 \\
\hline 82331 & Manaus & Amazonas & -60.01 & -3.1 & 61.25 \\
\hline 82562 & Marabá & Pará & -49.13 & -5.36 & 95.0 \\
\hline 83214 & Matupá & $\begin{array}{c}\text { Mato } \\
\text { Grosso }\end{array}$ & -54.91 & -10.25 & 285.0 \\
\hline 82240 & Parintins & Amazonas & -56.73 & -2.63 & 29.0 \\
\hline 83228 & Peixe & Tocantins & -48.35 & -12.01 & 242.49 \\
\hline 82915 & Rio Branco & Acre & -67.8 & -9.96 & 160.0 \\
\hline 83410 & Rondonopolis & $\begin{array}{c}\text { Mato } \\
\text { Grosso }\end{array}$ & -54.56 & -16.45 & 284.0 \\
\hline 82807 & Tarauaca & Acre & -70.76 & -8.16 & 190.0 \\
\hline 82317 & Tefé & Amazonas & -64.7 & -3.83 & 47.0 \\
\hline 82361 & Tucurui & Pará & -49.66 & -3.76 & 40.0 \\
\hline
\end{tabular}

*height above sea level.

described in Vicente-Serrano et al. (2010). However, we describe here its basic grounds:

Basically, the SPEI makes use of the difference between the monthly or weekly precipitation $(P)$ and potential evapotranspiration (PET). The PET values are computed following the approach by Thornthwaite (1948). That is, the monthly PET $(\mathrm{mm})$ is calculated as:

$$
\text { PET }=16 K\left(\frac{10 T}{I}\right)^{m}
$$

where $T$ is the monthly mean temperature $\left({ }^{\circ} \mathrm{C}\right), I$, is a heat index which is the sum of 12 monthly index values, $i$ :

$$
\begin{gathered}
i=\left(\frac{T}{5}\right)^{1.514} \\
m=6.75 \times 10^{-7} I^{3}-7.71 \times 10^{-5} I^{2} \\
+1.79 \times 10^{-2} I+0.492
\end{gathered}
$$

and $K$ is a correction factor computed as a function of the month and latitude.

$$
K=\left(\frac{N}{12}\right)\left(\frac{N D M}{30}\right)
$$

$N D M$ is the number of days of the month and $N$ is the maximum number of sun hours.

$$
N=\left(\frac{24}{\pi}\right) \omega_{s}
$$

where $\omega_{s}$ is the hourly angle of sun rising.

$$
\omega_{s}=\arccos (-\tan \phi \tan \delta)
$$

Here $\phi$ is the latitude in radians and $\delta$ is the solar declination in radians.

$$
\delta=0.4093 \operatorname{sen}\left(\frac{2 \pi J}{365}-1.405\right)
$$

where $J$ is the average Julian day of the month.

The difference between rainfall $P$ and $P E T$ for the $i$ -month, is computed as:

$$
D_{i}=P_{i}-P E T_{i}
$$

The computed $\mathrm{D}_{\mathrm{i}} v$ values are then aggregated at different timescales in the same way as that for computing SPI. That is, the difference $D$ in a given month $j$ and year $i$ depends on the timescale $k$ (e.g. 1, 3, 6,.., 24 months). We reproduce here the same example used by Vicente-Serrano et al. (2010). For instance, the accumulated difference for one month in a particular year $i$ with a 12-month timescale is calculated as:

$$
X_{i, j}^{k}=\sum_{l=13-k+j}^{12}\left(\mathrm{D}_{\mathrm{i}-1,1}\right)+\sum_{l=1}^{j}\left(\mathrm{D}_{\mathrm{i}, 1}\right), \text { if } \mathrm{j}<k
$$

and:

$$
X_{i, j}^{k}=\sum_{l=j-k+1}^{j}\left(\mathrm{D}_{\mathrm{i}, 1}\right), \text { if } \mathrm{j} \geq k
$$

Here, $D_{i, l}=P-P E T$ in the first month of the year $i$ in millimeters.

Different to SPI computation which uses a two parameter distribution (Gamma distribution), SPEI calculation requires a three-parameter distribution to model $D_{i}$ values for different timescales. In this case, Vicente-Serrano et al. (2010) proposed a log-logistic distribution function. It is instructive to recall here that its probability density function is:

$$
f(x)=\frac{\beta}{\alpha}\left(\frac{x-\gamma}{\alpha}\right)^{\beta-1}\left[1+\left(\frac{x-\gamma}{\alpha}\right)^{\beta}\right]^{-2}
$$

while its probability distribution function is:

$$
F(x)=\left[1+\left(\frac{\alpha}{x-\gamma}\right)^{\beta}\right]^{-1}
$$

where $\alpha, \beta$, and $\gamma$ are the scale, shape, and origin parameters, respectively. 
After that, the SPEI can be calculated as standardized values of $F(x)$ :

$$
\begin{array}{r}
S P E I=W-\frac{C_{0}+C_{1} W+C_{2} W^{2}}{1+d_{1} W+d_{2} W^{2}+d_{3} W^{3}}, \\
\text { where } W=\sqrt{-2 \ln (p)}, \text { for } p \leq 0.5
\end{array}
$$

where $p$ is the probability of exceeding a given $D$ value, $p=1-F(x), C_{0}=2.515517, \quad C_{1}=0.802853$, $C_{2}=0.010328, d_{1}=1.432788, d_{2}=0.189269$, $d_{3}=0.001308$. In addition, when $p>0.5$, it is replace by $1-p$ and the sign of the corresponding SPEI value is inverted. The software for computing the $S P E I$ isof public domain (Begueria and Vicente-Serrano, 2013).

\subsection{Rescaled range $(\mathrm{R} / \mathrm{S})$ analysis and Hurst exponent estimation}

Each time series corresponding to the number of days with precipitation by month and accumulated monthly rainfall was detrended for removing trend and any seasonal component (Shumway and Stoffer, 2006). Furthermore, Mandelbrot and Wallis (1969) recommended removing periodic structures before the application of the $R / S$ method:

$$
Y_{d i}=Y_{i}-\left(a+b t_{i}\right)
$$

where $Y_{d i}$ is the $i$ th detrended value at the $i$ th month $\left(t_{i}\right)$, $Y_{i}$ is the $i$ th observed (untransformed) record and $a$ and $b$ are the coefficients of the linear trend equation. This procedure transforms the original data into a residual time series. Thedetrended time series of days with precipitation by month were used for performing rescaled range $(R / S)$ analysis and to compute the Hurst exponent $\left(H_{d}\right.$ hereafter) (Hurst, 1951). In addition, Hurst exponents were also computed from each time series corresponding to the accumulated monthly rainfall $\left(H_{r}\right.$ hereafter). The mathematical basis of the rescaled range method is described in many papers (e.g. Hurst, 1951; Feder, 1988; Turcotte, 1997; Shi et al., 2013). Nevertheless, it could beuseful to recall here its fundamentals:

Assume a time series of a given meteorological variable $\{Y(\tau)\}(\tau=1,2, \ldots, m)$ and compute the mean value:

$$
Y_{\tau}=\frac{1}{\tau} \sum_{t=1}^{\tau} Y(t)
$$

After that we calculate the cumulative deviation as:

$$
Y_{t, \tau}=\sum_{t=1}^{\tau}\left[Y(t)-Y_{\tau}\right], 1 \leq t \leq \tau
$$

Define a range series:

$$
R(\tau)=\begin{array}{ll}
\max Y(t, \tau)- & \min Y(t, \tau) \\
1 \leq t \leq \tau & 1 \leq t \leq \tau
\end{array}
$$

The standard deviation series is defined as:

$$
S(\tau)=\sqrt{\left(\frac{1}{\tau} \sum_{t=1}^{\tau}\left[Y(t)-Y_{\tau}\right]^{2}\right)}
$$

Finally, the rescaled range $(R / S)$ is a power law of the time lag $(\tau)$ :

$$
(R / S)_{\tau}=c \tau^{H}
$$

where $H$ is the Hurst exponent $(0<H<1)$ and $c$ is a constant representing the rescaled range at a unit time scale (e.g. $\tau=$ one day). In practice, $c$ and $H$ are dependent constants.

Eq. (19) can be used with empirical or simulated observations after a log-log transformation:

$$
\log [R / S]_{\tau}=\log (c)+H \log (\tau)
$$

The value of the Hurst exponent can be used to predict the future trend of a meteorological variable based on its current behavior. For example:

a. $H=0.5$ indicates that rainfall variance is due to independent, random (Gaussian) processes. That is, there is no correlation between past and future rainfall events.

b. $0.5<H<1$ signifies that past and future rainfall events are positively correlated. This positive trend (persistence) can span several time scales.

c. $0<H<0.5$ implies that past and future rainfall events are negatively correlated in time. Such a negative trend (antipersistence) can also span several time scales.

The Hurst exponents estimated from the detrended number of days with precipitation by months are represented by $H_{d}$ while those computed from monthly rainfall are denoted by $H_{r}$.

All the statistical analyses were conducted using StatisticaTM Software Package (StatSoft Inc., 2011).

\section{Results and Discussion}

Table 2 shows the descriptive statistics of monthly rainfall corresponding to the whole available time period for each meteorological station. That classical analysis revealed a large spatio-temporal variability in terms of coefficient of variation $(\mathrm{CV})$. It ranged from $C V=50.7 \%$ for Tefé (Amazonas state) to $C V=103 \%$ for Peixe (Tocantins state). The maximum precipitation values were registered in the Northern-Northeastern parts of the basin. For example, Parintins (Amazonas state) recorded $773.3 \mathrm{~mm}$ while Belem (Pará state) registered $742.5 \mathrm{~mm}$. Note however that 9 out of 15 sites recorded months with zero rainfall. In general this information agrees, to some extent, with the mechanism of moisture transport and convergence evaluated by many simulation models (Martins 
Table 2. - Descriptive statistics of monthly rainfall

\begin{tabular}{lccccc}
\hline Location & $\begin{array}{c}\text { Mean } \\
(\mathrm{mm})\end{array}$ & $\begin{array}{c}\text { Min. } \\
(\mathrm{mm})\end{array}$ & $\begin{array}{c}\text { Max. } \\
(\mathrm{mm})\end{array}$ & $\begin{array}{c}\text { St. Dev. } \\
(\mathrm{mm})\end{array}$ & $\begin{array}{c}\text { CV } \\
(\%)\end{array}$ \\
\hline Belem & 278.3 & 41.3 & 742.5 & 155.7 & 56.0 \\
Boa Vista & 151.7 & 0.0 & 667.5 & 147.5 & 97.2 \\
Diamantino & 165.3 & 0.0 & 638.3 & 148.2 & 89.5 \\
Itacoatiara & 213.7 & 1.4 & 605.0 & 143.5 & 67.1 \\
Macapá & 207.8 & 0.0 & 679.2 & 155.9 & 75.0 \\
Manaus & 196.3 & 0.6 & 553.0 & 131.0 & 66.7 \\
Marabá & 148.9 & 0.0 & 517.8 & 132.5 & 88.9 \\
Matupá & 175.4 & 0.0 & 587.5 & 155.1 & 88.4 \\
Parintins & 220.1 & 1.3 & 773.3 & 162.2 & 73.7 \\
Peixe & 118.7 & 0.0 & 527.5 & 122.6 & 103 \\
Rio Branco & 164.5 & 0.0 & 512.2 & 116.5 & 70.8 \\
Rondonopolis & 108.0 & 0.0 & 572.2 & 110.4 & 102 \\
Tarauaca & 192.7 & 2.0 & 513.2 & 115.5 & 59.9 \\
Tefé & 210.7 & 26.0 & 637.2 & 106.8 & 50.7 \\
Tucurui & 206.2 & 0.0 & 732.3 & 178.5 & 86.5 \\
\hline
\end{tabular}

et al., 2015). On the other hand, Table 3 presents the descriptive statistics of monthly mean temperature for all the sites. Mean temperature showed less variability as compared to precipitation in terms of $C V$ values. Coefficient of variation $(\mathrm{CV})$ spanned from $2.2 \%$ for Belem (Pará state) to 6.3\% for Rondonopolis (Mato Grosso state). Figure 2 presents the time series corresponding to monthly rainfall and monthly mean temperature for three selected sites (Boa Vista, Rondonopolis and Tefé). We found a slight increase of monthly mean temperature as shown by the trend line. For example, an increase of $0.47{ }^{\circ} \mathrm{C}$ was detected in Boa Vista (Roraima state), $0.70{ }^{\circ} \mathrm{C}$ in Rondonopolis (Mato Grosso state) and $0.31{ }^{\circ} \mathrm{C}$ in Tefé

Table 3. - Descriptive statistics of monthly mean temperature.

\begin{tabular}{lccccc}
\hline Location & Mean $\left({ }^{\circ} \mathrm{C}\right)$ & Min. $\left({ }^{\circ} \mathrm{C}\right)$ & Max. $\left({ }^{\circ} \mathrm{C}\right)$ & St. Dev. $\left({ }^{\circ} \mathrm{C}\right)$ & $\mathrm{CV}(\%)$ \\
\hline Belem & 26.9 & 25.5 & 28.1 & 0.59 & 2.2 \\
Boa Vista & 28.1 & 25.7 & 30.1 & 0.95 & 3.4 \\
Diamantino & 25.3 & 21.3 & 28.3 & 1.47 & 5.8 \\
Itacoatiara & 27.3 & 22.8 & 30.1 & 1.00 & 3.6 \\
Macapá & 27.4 & 25.3 & 29.3 & 0.98 & 3.6 \\
Manaus & 27.4 & 25.2 & 30.2 & 1.00 & 3.6 \\
Marabá & 27.7 & 25.8 & 29.8 & 0.92 & 3.3 \\
Matupá & 25.4 & 23.7 & 27.7 & 0.76 & 3.0 \\
Parintins & 27.9 & 25.2 & 30.1 & 1.06 & 3.8 \\
Peixe & 26.2 & 22.9 & 29.0 & 1.15 & 4.4 \\
Rio Branco & 25.2 & 19.8 & 26.9 & 1.06 & 4.2 \\
Rondonopolis & 25.2 & 21.0 & 28.7 & 1.60 & 6.3 \\
Tarauaca & 25.8 & 20.3 & 27.2 & 0.81 & 3.2 \\
Tefé & 27.0 & 24.9 & 28.9 & 0.66 & 2.4 \\
Tucurui & 27.7 & 26.0 & 29.7 & 0.75 & 2.7 \\
\hline
\end{tabular}

(Amazonas state. A similar trend was found for all the investigated time series. In the present study, the mean value of temperature increase was $0.71{ }^{\circ} \mathrm{C}$ for the $15 \mathrm{stu}-$ died locations. This is consistent with the fact that, at a global scale, mean temperature has increased about $0.6{ }^{\circ} \mathrm{C}$ over the last century (Molla et al., 2006). According to an IPCC report (IPCC, 2007), an increasing rate of warming has occurred over the last 25 years.

Figure 3 shows the SPEI oscillation for all the investigated locations. The percentage of SPEI values in the nearnormal class $(-1 \leq S P E I \leq 1)$ ranged from a minimum $59.8 \%$ for Peixe (Tocantins state) to a maximum value $69.7 \%$ for Tarauaca (Acre state) (Table 4). On the other hand, the proportion of $S P E I$ values within the moderate to extremely dry category $(-3 \leq S P E I<-1)$ ranged from $14.5 \%$ for Diamantino (Mato Grosso state) to $21.5 \%$ for Peixe(Tocantins state) (Table 4). In particular, we found important moderate to extreme droughtperiodsfor five investigated sites (e.g. a run of more than 12 consecutive months with SPEI <-1) (Fig. 3): for example Matupá (Mato Grosso state) approximately from May 2001 to April 2003 and Rondonopolis (Mato Grosso state) from March 2001 to June 2003. This is significant as Mato Grosso is located within the so-called deforestation arc (Bonini et al., 2014). One site from Amazonas state also showed more than 12 months of moderate to extreme drought: Itacoatiara (from August 2005 to October 2006. The longer period of moderate to extreme drought was detected for Peixe (Tocantins state) and lasted approximately 16 months (from March 2013 to October 2014) while Rio Branco (Acre state) showed a 14-month period of moderate to extreme dry (from March/April 2011 to May 2012 approximately). That residence time is more than $8 \%$ of the time within drought categories. Many authors have identified deforestation as the main cause of such a hydrological alteration (Moraes et al., 2013) whileother authors hold that drought is a multi-causal phenomenon (Zeng et al., 2008). Based on SPEI classification, the 9-month timescale detected hydrological drought in different regions of the Amazon basin spanning different periods of time. It could be useful to consider other SPEI time scales in the future. Note however, that SPEI values based on a single 9-month timescale detected drought periods unobserved in other studies. It is due, in part, to the insertion of mean temperature into the computations. We are well aware that availability of large precipitation and temperature records can improve the SPEI interpretation. However, we considered that the derived information for the last 15 years could be valuable within the context of the present investigation.

The Hurst exponent estimated from the detrended number of days with precipitation by month ranged from $H_{d}=0.382$ (strong antipersistence) for Diamantino (Mato Grosso) to $H_{d}=0.636$ (strong persistence) for Tefé (Amazonas) (Table 5). Based on the confidence limits of $H_{d}$ 

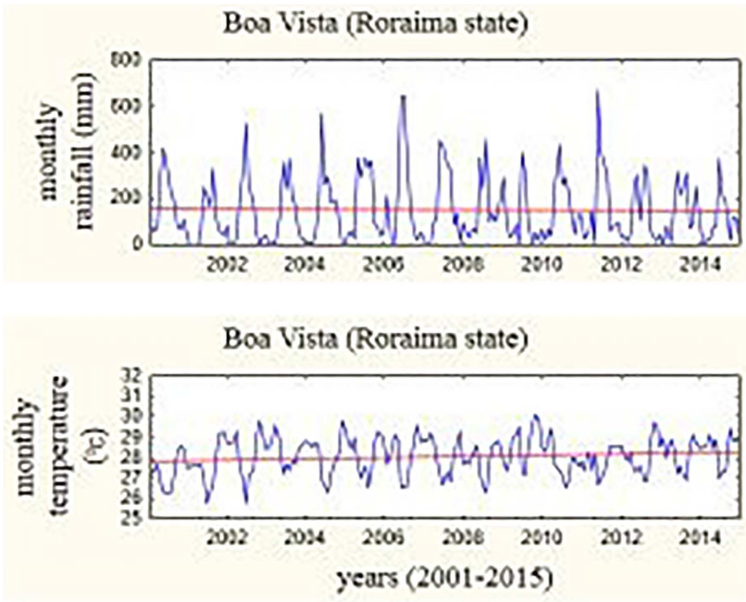

Tefé (Amazonas state)

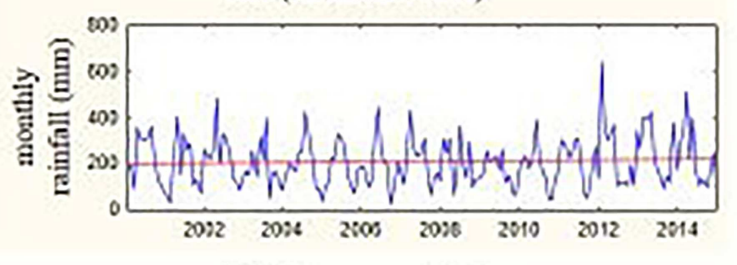

Tefe (Amazonas state)

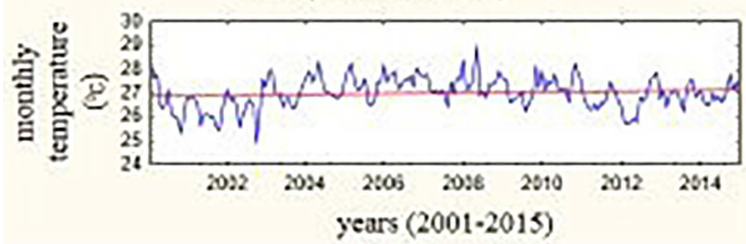

Rondonopolis (Mato Grosso state)

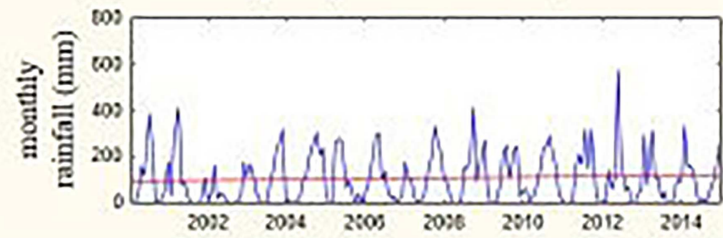

Rondonopolis (Mato Grosso state)

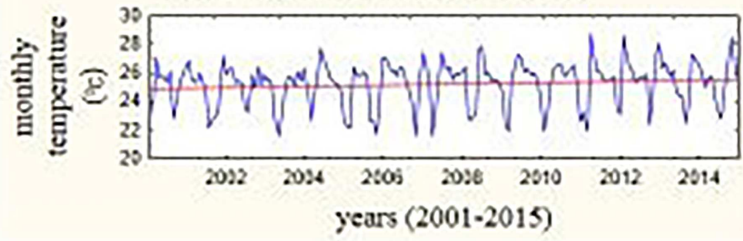

Figure 2 - Accumulated monthly rainfall and mean monthly temperature for three selected locations.

estimates, those time series corresponding to Macapá (Amapá state), Marabá (Pará state), Matupá (Mato Grosso), Rio Branco (Acre state) and Tarauaca (Acre state) were very close to the theoretical Gaussian limit $H_{d}=0.5 \quad\left(H_{d}=0.533 \pm 0.017, H_{d}=0.530 \pm 0.020\right.$, $H_{d}=0.468 \pm 0.022, H_{d}=0.525 \pm 0.027$ and $H_{d}=0.490$ \pm 0.022 , respectively). That is, at a first criterion we could accept the hypothesis on the independence (e.g. random increments) between past and future daily rainfall patterns. This suggests, to some extent, that those variables close connected to daily rainfall patterns such as air temperature, atmospheric moisture distribution or convective processes also could show random (Gaussian) variability in those particular sites (Fraedrich, 2002). In particular, $H_{d}>$ 0.5 indicates that present and future daily rainfall patterns tend to persist, at least, in the near future. Some sites located at Central to Northeast Amazonia showed moderated persistence in the monthly number of days with rainfall occurrence (e.g. Belem, Manaus, Parintins) while some zones located at South to Southwest Amazonia presented moderated anti-persistence (e.g. Peixe, Rondonopolis) (Table 5). In this case, the observed daily rainfall patterns show a reversal trend. Hurst exponents estimated from detrended time series of accumulated monthly rainfall ranged from $H_{r}=0.302$ for Peixe (Tocantins state) to $H_{r}=$ 0.548 for Tefé (Amazonas state). Note that most $H_{r}$ values were consistently below 0.5 (Table 5 ). We found a significant linear relationship (significance level $p<0.05$ ) between Hurst exponents estimated from the number of days with precipitation by month $\left(H_{d}\right)$ and monthly mean rainfall (Fig. 4):

$$
\begin{aligned}
& H_{d}=0.44(0.13) \log \left(P_{\text {mean }}\right) \\
& -0.485(0.29), \quad R=0.793
\end{aligned}
$$

where $\log \left(P_{\text {mean }}\right)$ is the logarithm of mean rainfall values as shown in Table 2.

Eq. (21) conveys information on the potential utility of Hurst analysis. Irrespective of the amount of daily rainfall, the scale invariance of detrendednumber of dayswith precipitation by month determines the randomness, persistence or anti-persistence of rainy patterns as a whole. It also suggests thatmoving from anti-persistence to persistence as a function of daily rainfall could be related toother scaling processes showingnegative correlation and trend reversal or positive correlation between past and 

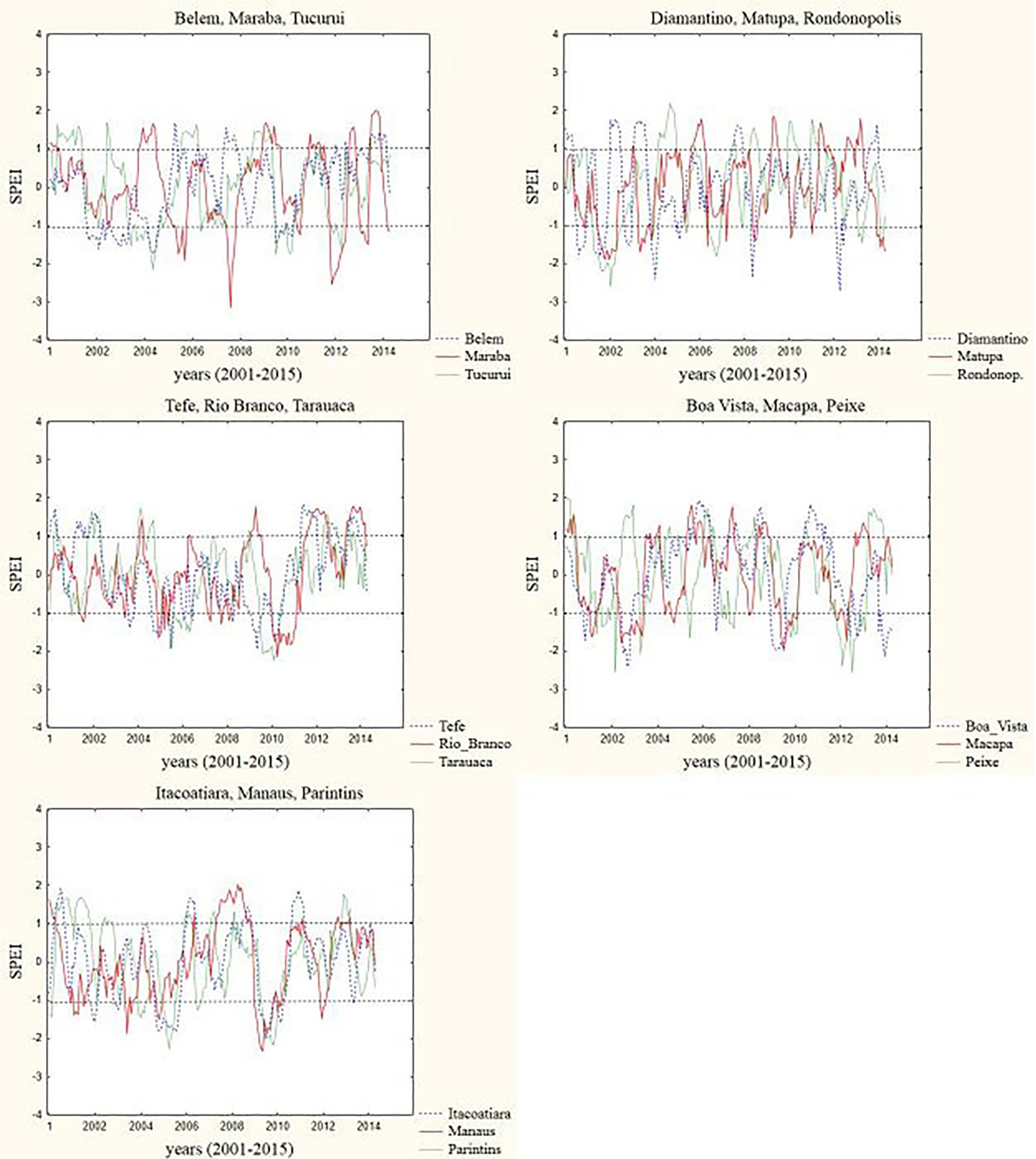

Figure 3 - SPEI (9-month timescale) oscillation for all the investigated sites.

present wet states and non-periodic cyclical pattern. For example, a typical case is the evaporation to precipitation ratio (Millán et al., 2009). In particular, the long-term memory effect could be induced by low frequency atmospheric variability (Fraedrich, 2003). For example, Manabe and Delworth (1990) considered that soil moisture can contribute to such low frequency atmospheric variability. The extreme cases of anti-persistence in terms of $H$ value were found for Diamantino $\left(H_{d}=0.382\right.$ and $\left.H_{r}=0.315\right)$ and Peixe $\left(H_{d}=0.428\right.$ and $\left.H_{r}=0.302\right)$. This indicates that actual dry patterns detected in that zonescanintensify in the future so as the probability of extreme events (e.g. droughts). For example,Diamantino showed a rainfall decrease of about $-12 \mathrm{~mm}$ while Tefé $\left(H_{d}=0.636\right.$ and $H_{r}=$ 0.548 ) presented an increase of approximately $+19 \mathrm{~mm}$ in the last 15 years. That information can be obtained from the linear trend of the original, untransformed, time series. In meteorological terms, few days with intense, local and 
Table 4. - Percentage of $S P E I$ values in approximately normal (-1 $\leq S P E I$ $\leq 1)$ and moderate to extremely dry $(-3 \leq S P E I<-1)$ classes.

\begin{tabular}{lcc}
\hline Location & $-1 \leq S P E I \leq 1(\%)$ & $(-3 \leq S P E I<-1)$ \\
\hline Belem & 68.0 & 18.0 \\
Boa Vista & 65.6 & 16.8 \\
Diamantino & 67.7 & 14.5 \\
Itacoatiara & 65.0 & 20.3 \\
Macapá & 61.0 & 20.9 \\
Manaus & 65.1 & 16.8 \\
Marabá & 61.7 & 15.2 \\
Matupá & 66.8 & 18.0 \\
Parintins & 62.7 & 16.2 \\
Peixe & 59.8 & 21.5 \\
Rio Branco & 65.1 & 16.4 \\
Rondonopolis & 62.7 & 19.2 \\
Tarauaca & 69.7 & 15.7 \\
Tefé & 62.2 & 16.2 \\
Tucurui & 60.4 & 18.6 \\
\hline
\end{tabular}

short-lived rainfall events (e.g. convective rainfall events) in a month can produce a larger accumulated monthly rainfall than many days with stratiform rainfall. On this basis, we could hypothesize that $H_{d}>0.5$ and $H_{r}<0.5$ indicate that persistence of the number of days with precipitation by month combined with anti-persistence of the accumulated monthly rainfall are due to the relevance of stratiform rainfall more than convective rainfall(e.g. Belem, Tucurui) (Table 5). Thatassumption agrees with previous results derived from wavelet analysis by Venugopal and Foufoula-Georgiou (1996). Wang et al. (2010), using detrended fluctuation analysis, alsofound shortrange and long-range correlations for the Amazon. Those authors also considered soil moisture as an important driving agent in land-atmosphere interactions. In particular, Mato Grosso showed a forest loss of about $13.4 \%$ in the period 2001-2012. That is, deforestation can intensify evaporation and soil moisture shortage. In fact, soil moisture deficit combined with high temperature affects evapotranspiration which also influences SPEI values. This could alsoexplain, to some extent, the anti-persistent rainfall patterns in some studied sites. Furthermore, evaporation can exceed precipitation in those deforested areas which could modify the hydrological cycle (Millán et al., 2009). We do not have any information on previous works relating scaling indexes as derived from fractal concepts to first order statistics (e.g. mean values) of hydrometeorological variables. SPEI and Hurst exponents are valuable parameters for identifying vulnerable areas in terms of extreme events (e.g. droughts and intense rainfall). It is also interesting that orographic factors (e.g. height above sea level) can also determine the nonlinear scaling of rainfall events. If one correlates the height above sea level (Table 1) with $H_{d}$ (Table 5) will find a significant negative linear relationship between both parameters $(R=-0.776, p<0.05)$. This result is physically sound since one could expect a drier atmosphere as the height above sea level increases. Finally, we could identify two potential utilities of Hurst exponents for conducting hydrometeorological investigationsin the Amazon basin. First of all, $H$ values can be incorporated within nonlinear models for making rainfall events simulation and second, the existence of scale invariance as represented by Hurst exponents is a key component for up-scaling atmospheric

Table 5. - Rescaled range analysis parameters[in parenthesis lower (-) and upper (+) confidence limits for a level $\alpha=0.05]$.

\begin{tabular}{|c|c|c|c|c|c|c|}
\hline Location & $c_{d}$ & $H_{d}$ (days with rainfall) & $R^{*}$ & $c_{r}$ & $H_{r}($ monthly rainfall $)$ & $R^{*}$ \\
\hline Belem & $1.60( \pm 0.16)$ & $0.552( \pm 0.015)$ & 0.950 & $1.56( \pm 0.031)$ & $0.409( \pm 0.016)$ & 0.965 \\
\hline Boa Vista & $1.73( \pm 0.17)$ & $0.425( \pm 0.014)$ & 0.954 & $1.37( \pm 0.028)$ & $0.451( \pm 0.014)$ & 0.976 \\
\hline Diamantino & $1.81( \pm 0.14)$ & $0.382( \pm 0.021)$ & 0.979 & $2.03( \pm 0.038)$ & $0.315( \pm 0.020)$ & 0.950 \\
\hline Itacoatiara & $1.68( \pm 0.08)$ & $0.543( \pm 0.014)$ & 0.993 & $1.74( \pm 0.047)$ & $0.413( \pm 0.025)$ & 0.981 \\
\hline Macapá & $1.70( \pm 0.20)$ & $0.533( \pm 0.017)$ & 0.910 & $1.61( \pm 0.032)$ & $0.405( \pm 0.017)$ & 0.963 \\
\hline Manaus & $1.53( \pm 0.16)$ & $0.566( \pm 0.018)$ & 0.951 & $1.43( \pm 0.029)$ & $0.439( \pm 0.015)$ & 0.983 \\
\hline Marabá & $1.69( \pm 0.20)$ & $0.530( \pm 0.020)$ & 0.950 & $1.78( \pm 0.036)$ & $0.382( \pm 0.019)$ & 0.950 \\
\hline Matupá & $1.71( \pm 0.16)$ & $0.468( \pm 0.022)$ & 0.954 & $2.10( \pm 0.042)$ & $0.305( \pm 0.022)$ & 0.931 \\
\hline Parintins & $1.54( \pm 0.09)$ & $0.567( \pm 0.015)$ & 0.991 & $1.46( \pm 0.031)$ & $0.434( \pm 0.016)$ & 0.970 \\
\hline Peixe & $1.72( \pm 0.10)$ & $0.428( \pm 0.027)$ & 0.986 & $2.08( \pm 0.042)$ & $0.302( \pm 0.022)$ & 0.942 \\
\hline Rio Branco & $1.71( \pm 0.12)$ & $0.525( \pm 0.027)$ & 0.976 & $1.70( \pm 0.034)$ & $0.379( \pm 0.018)$ & 0.957 \\
\hline Rondonopolis & $1.72( \pm 0.17)$ & $0.430( \pm 0.021)$ & 0.912 & $1.25( \pm 0.025)$ & $0.469( \pm 0.013)$ & 0.989 \\
\hline Tarauaca & $1.73( \pm 0.10)$ & $0.490( \pm 0.022)$ & 0.985 & $1.47( \pm 0.029)$ & $0.442( \pm 0.015)$ & 0.973 \\
\hline Tefé & $1.46( \pm 0.14)$ & $0.636( \pm 0.013)$ & 0.958 & $0.96( \pm 0.029)$ & $0.548( \pm 0.015)$ & 0.982 \\
\hline Tucurui & $1.68( \pm 0.16)$ & $0.544( \pm 0.02)$ & 0.950 & $1.65( \pm 0.032)$ & $0.400( \pm 0.017)$ & 0.961 \\
\hline
\end{tabular}

${ }^{*}$ Correlation coefficient. 


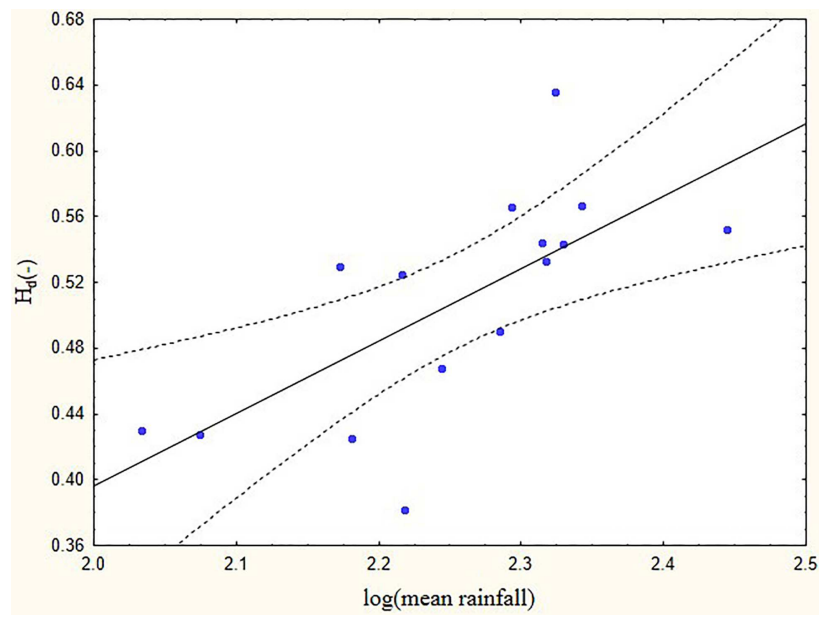

Figure 4 - Linear relationship between Hurst exponent $\left(H_{d}\right)$ and the logarithm ofthe accumulated monthly rainfall.

processes. That is, yearly rainfall dynamics could be modeled by actual monthly patterns.

\section{Conclusion}

We used a 9-month timescalestandardized precipitation evapotranspiration index (SPEI) for investigating the current state of hydrometeorology in 15 sites of the Amazonian rainforest. Even thought the percentage of SPEI values within the near normal class was over $59 \%$, five sites showedmore than 12 consecutive months of moderate to extreme drought $(-3 \leq S P E I<-1)$. Hydrological droughts were present in different years within the considered time periodaccording to SPEI classification. In addition, we performed re-scaled range analysis $(R / S)$ for estimating the Hurts exponent corresponding to each detrended time series of days with precipitation by month and monthly rainfall. There was a positive linear relationship between the Hurst exponent $\left(H_{d}\right)$ and the monthly mean rainfall. This could help to incorporate theoretical concepts of scaling for interpreting the evolution in time ofrainfall events. As Amazonia climate is very complex, future investigations could be conducted to test whether persistence $(H>0.5)$ or anti-persistence $(H<0.5)$ of rainfall time series detected at smaller timescales (e.g. days) could be replicated at larger timescales (e.g. months or year. This would require larger data sets. Hurst exponents could be also associated to the rainfall generating mechanism (e.g. convective or stratiform rainfall). In terms of $H_{d}$ and $H_{r}$, different Amazonian regions showed different rainfall regimes. That is, moderate persistence at Central to Northeast Amazonia to moderate anti-persistence at South to Southwest Amazonia with extreme cases at Mato Grosso state.

\section{Acknowledgments}

The authors want to acknowledge Instituto Nacional de Meteorologia (INMET, Brazil) for providing access to the rainfall and temperature data sets used in the present study. Dr. Humberto Millán is grateful to the Universidade do Estado do Amazonas (Manaus, Brazil) for the valuable support during his position as an invited Professor of Physics. Jakeline Rabelo Lima was supported by the FAPEAM Program (Fundação de Amparo á Pesquisa do Estado do Amazonas) under grant 22/2013-GR/UEA.

\section{References}

ANDREOLI, R.V.; SOUSA, R.A.F.; KAYANO, M.T.; CANDIDO, L.A. Seasonal anomalous rainfall in the central and eastern Amazon and associated anomalous oceanic and atmospheric patterns. International Journal of Climatology, v. 32, p. 1193-1205, 2012

ARAGÃO, L.E.O.C.; MALHI, Y.; BARBIER, N.; LIMA, A.; SHIMABUKURU, Y.; ANDERSON, L.; SAATCHI, S. Interactions between rainfall, deforestation and fires during recent years in the Brazilian Amazonia. Philosophical Transactions of the Royal Society B, London, v.363, n. 1498, p. 1779-1785, 2012

BEGUERIA, S.; VICENTE-SERRANO, S.M. Calculation of the standardized precipitation-evapotranspiration index. User manual, version 1.6, 16 p., available at http://sac.csic.es/ spei, 2013

BONINI, I.; RODRIGUES, C.; DALLACORT, R.; JUNIOR, B. H.M.; CARVALHO, M.A.C. Rainfall and deforestation in the municipality of Colíder, southern Amazon. Revista Brasileira de Meteorologia, v.29, n.4, p. 483-493, 2014

CHEN, J.; CARLSON, B.E.; DEL GENIO, A.D. Evidence for strengthening of the tropical circulation in the 1990s. Science, v. 295, p. 838-841, 2002

FEDER, J. Fractals. 2nd ed. Plenum Press, New York, 283p., 1988

FRAEDRICH, K. Fickian diffusion and Newtonian cooling: A concept for noise induced climate variability with longterm memory?. Stochastics and Dynamics, v. 2, n. 3, p. 403-412, 2002

FRAEDRICH, K. Predictability: short- and long-term memory of the atmosphere. In Boffetta, G., Lacorata, G., Visconti, G., Vulpiani, A. (eds.), Chaos in Geophysical Flows, International Summer School on Atmospheric and Oceanic Sciences, L'Aquila, Italy, p. 63-104, 2003

HURST, H.E. Long-term storage capacity of reservoirs. Transactions of the American Society of Civil Engineering, v.116, p. 770-799, 1951

INTERGOVERNMENTAL PANEL ON CLIMATE CHANGE. Climate Change 2001: Impacts, Adaptation, and Vulnerability. Contribution of Working Group II to the Third Assessment Report of the Intergovernmental Panel on Climate Change. Cambridge University Press, Cambridge , United Kingdom, 1032 p., 2001 
INTERGOVERNMENTAL PANEL ON CLIMATE CHANGE. Climate change 2007: The Physical Science Basics. In Solomon, S., Qin, D., Manning, M., Chen, Z., Marquis, M., Averyt, K.B., Tignor, M., Miller, H.L. (eds.), Contribution of Working Group I to the Fourth Assessment Report of the Intergovernmental Panel on Climate Change, Cambridge University Press, Cambridge, United Kingdom and New York, NY, USA, 996 p., 2007.

MANABE, S.; DELWORTH, T. The temporal variability of soil wetness and its impact on climate, Climate Change, v. 16, p. $185-192,1990$

MANDELBROT, B.B; WALLIS, J.R. Some long-run properties of geophysical records. Water Resources Research, v. 5, p. 242-259, 1969

MARENGO, J. Interdecadal variability and trends of rainfall across the Amazonian basin. Theoretical and Applied Climatology, v.78, p. 79-96, 2004

MARTINS, G.; VON RANDOW, C.; SAMPAIO, G.; DOLMAN, A.J. Precipitation in the Amazon and its relationship with moisture transport and tropical Pacific and Atlantic SST from the CMIP5 simulation. Hydrology and Earth System Sciences (Discussions), v. 12, p. 671-704, 2015

McKEE, T.B.; DOESKEN, N.J.; KLEIST, J. The relationship of drought frequency and duration to time scales. Preprints, $8^{\text {th }}$ Conference on Applied Climatology, 17-22 January, American Meteorological Society, Anaheim, CA, p.179184,1993

MILLÁN, H.; KALAUZI, A.; LLERENA, G.; SUCOSHAÑAY, J.; PIEDRA, D. Meteorological complexity in the Amazonian area of Ecuador: An approach based on dynamical system theory. Ecological Complexity, v. 6, p. 278-285, 2009

MISHRA, A.K., SINGH, V.P. A review of drought concepts. Journal of Hydrology, v. 391, p. 202-216, 2010

MOLLA, M.D.K.I.; RAHMAN, M.S.; SUMI, A.; BANIK, P. Empirical mode decomposition analysis of climate changes with special reference to rainfall data. Discrete Dynamics in Nature and Society, v. 2006, p. 1-17, 2006

MORAES, E.C.; FRANCHITO, S.H.; RAO, V.B. Amazonian deforestation: impact of global warming on the energy balance and climate. Journal of Applied Meteorology and Climatology, v. 52, n. 3, p. 521-530, 2013

PALMER, W. Meteorological Drought. Research Paper 45, US Weather Bureau, Washington, D. C., 1965

SHI, P.; MA, X.; CHEN, X.; QU, S.; ZHANG, Z. Analysis of variation trends in precipitation in an upstream catchment of Huai river. Mathematical Problems in Engineering, v. 2013, p. 1-11, 2013

SHUMWAY, R.H; STOFFER, D.S. Time Series Analysis and Its Applications. 2nd ed. Springer Science+Business Media, 588 p., 2006

STATSOFT, INC. Statistica (Data Analysis Software System), version 10, Tulsa, OK, 2011

THORNTHWAITE, C.W. An approach toward a rational classification of climate. Geographical Review, v. 38, p. 55-94, 1948

TSAKIRIS, T.; VANGELIS, H. Establishing a drought index incorporating evapotranspiration. European Water, v. 9/ 10 , p. 3-11, 2005

TURCOTTE, D.L. Fractals and Chaos in Geology and Geophysics. 2nd ed. Cambridge University Press, 412 p., 1997

VENUGOPAL, V.; FOUFOULA-GEORGIOU, E. Time-frequency-scale analysis of high resolution temporal rainfall using wavelet packets. Journal of Hydrology, v. 187, p. 327, 1996

VICENTE-SERRANO, S.M.; BEGUERÍA, S.; LÓPEZ-MORENO, J.I. A multiscalar drought index sensitive to global warming: The Standardized Precipitation Evapotranspiration Index. Journal of Climate, v.23, n.7, p.1696-1718, 2010

WANG, G.; DOLMAN, A.J.; BLENDER, R.; FRAEDRICH, K. Fluctuation regimes of soil moisture in ERA-40 re-analysis data. Theoretical and Applied Climatology, v. 99, p. 1-8, 2010

WILDHITE, D.A.; GLANTZ, M.H. Understanding the drought phenomenon: The role of definitions. Water International Journal, v.10, p. 111-120, 1985

WORLD METEOROLOGICAL ORGANIZATION. Standardized Precipitation Index User Guide. World Meteorological Organization, n. 1090, 2012

YOON, J.H.; ZENG, N. An Atlantic influence on Amazon rainfall. Climate Dynamics, v. 34, p. 249-264, 2010

ZENG, N.; YOON, J.H.; MARENGO, J.A.; SUBRAMANIAM, A.; NOBRE, C.A.; MARIOTTI, A.; NEELIN, J.D. Causes and impacts of the 2005 Amazon drought. Environmental Research Letters, v. 3, p.1-9, 2008

ZHOU, X.; PERSAUD, N.; WANG, H. Periodicities and scaling parameters of daily rainfall over semi-arid Botswana. Ecological Modelling, v. 182, p. 371-378, 2005

This is an Open Access article distributed under the terms of the Creative Commons Attribution License, which permits unrestricted use, distribution, and reproduction in any medium, provided the original work is properly cited. 